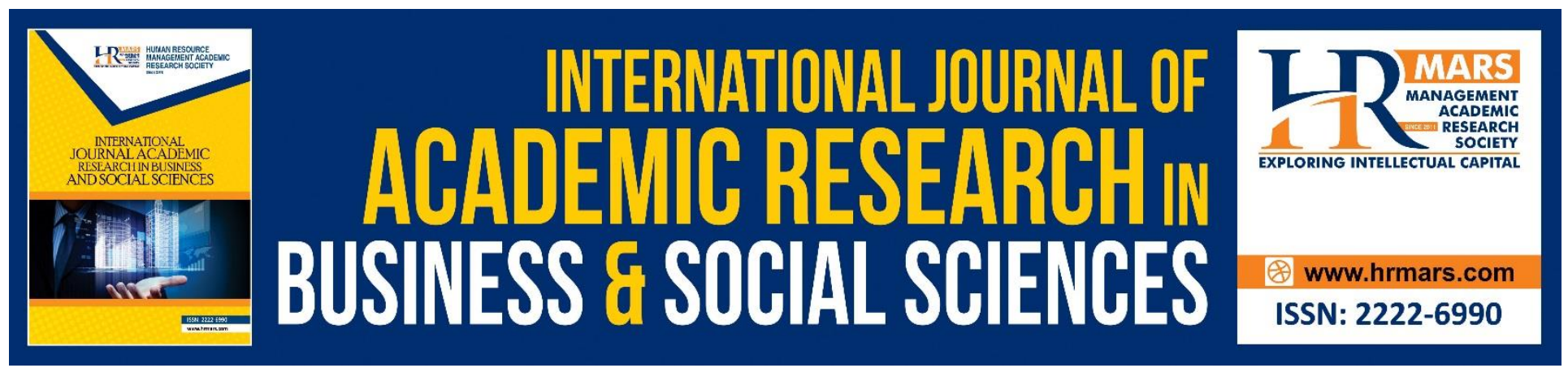

\title{
The Service Quality Analysis and Satisfaction of Tourists in Tanzania Hotel Industry
}

Burhan, Ahmad Mtengwa, Mayasa Mussa Kalinga

To Link this Article: http://dx.doi.org/10.6007/IJARBSS/v8-i11/4939

DOI: $10.6007 /$ IJARBSS/v8-i11/4939

Received: 11 Oct 2018, Revised: 04 Nov 2018, Accepted: 06 Dec 2018

Published Online: 13 Dec 2018

In-Text Citation: (Burhan \& Kalinga, 2018)

To Cite this Article: Burhan, A. M., \& Kalinga, M. M. (2018). The Service Quality Analysis and Satisfaction of Tourists in Tanzania Hotel Industry. International Journal of Academic Research in Business and Social Sciences, 8(11), 646-659.

Copyright: (C) 2018 The Author(s)

Published by Human Resource Management Academic Research Society (www.hrmars.com)

This article is published under the Creative Commons Attribution (CC BY 4.0) license. Anyone may reproduce, distribute, translate and create derivative works of this article (for both commercial and non-commercial purposes), subject to full attribution to the original publication and authors. The full terms of this license may be seen at: http://creativecommons.org/licences/by/4.0/legalcode

Vol. 8, No. 11, 2018, Pg. 646 - 659

Full Terms \& Conditions of access and use can be found at http://hrmars.com/index.php/pages/detail/publication-ethics 


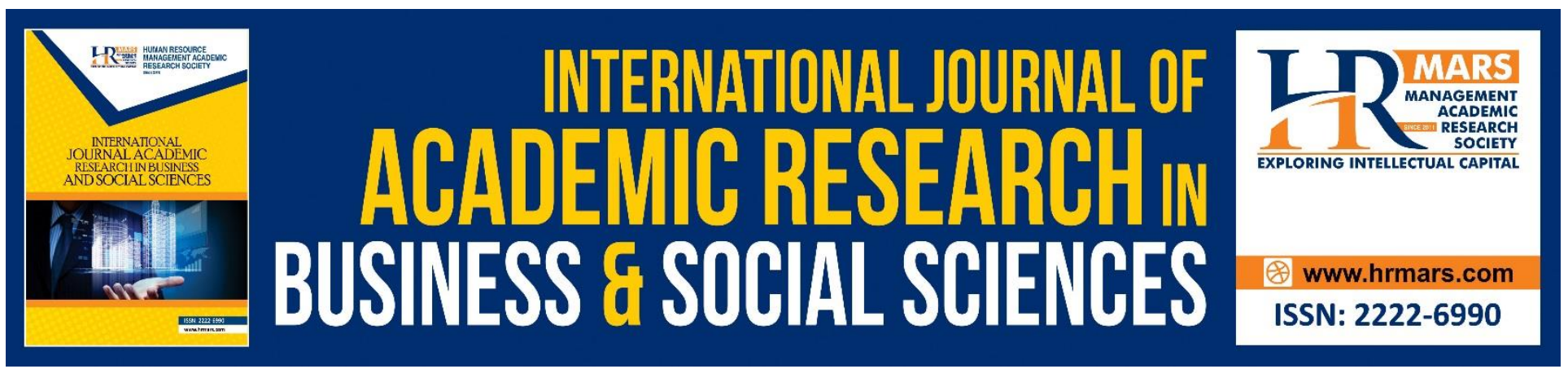

\title{
The Service Quality Analysis and Satisfaction of Tourists in Tanzania Hotel Industry
}

\author{
Dr. Burhan, Ahmad Mtengwa \\ Centre for Foreign Relations, Department of Economic Diplomacy \\ Email: mtengwa@hotmail.com \\ Mayasa Mussa Kalinga \\ Centre for Foreign Relations, Department of Economic Diplomacy \\ Email: maya.kalinga@gmail.com
}

\begin{abstract}
The study intended to find out how consumers (tourists) perceive service quality and whether they are satisfied with Services offered by hotels in Tanzania. The study was conducted in tourist hotels from Dar-es -salaam Tanzania. The general objectives of the study were to determine overall service quality perceived by tourists in Tanzania hotels and identify dimension that bring satisfaction to the tourist. From the study the researcher used a self-completion questionnaire developed from the SERVQUAL instrument suggested by Parasuraman, Zeithaml, and Berry (1988), and distributed to 150 respondents in Dar-es-salaam, Tanzania to determine their perceptions of service quality in hotel industry and the model used dimensions which include Tangibility, Reliability, Responsiveness, Assurance, Empathy and Price. The researcher used secondary methods of data collection of which were previously gathered by some other researcher such as project reports, books, internet, journal and documentary review. The researcher finds out that the overall service quality was perceived low (-17.4), Meaning expectations exceeded perceptions of services. Thus the actual hotel services offered to tourists in Tanzania are less than what was expected because almost every dimension of service quality brings tourist dissatisfaction. According to research findings and discussion made in this study the researcher recommends that, Tanzanian hotel have to improve performance on all the dimensions of service quality which includes Tangibility, Reliability, Responsiveness, Assurance, Empathy and Price in order to increase tourist satisfaction and enable them maintain high level of competitiveness with other countries.
\end{abstract}

Keywords: Customer Satisfaction, Quality Service, Tourist, Hotel Industry 
INTERNATIONAL JOURNAL OF ACADEMIC RESEARCH IN BUSINESS AND SOCIAL SCIENCES

Vol. 8, No. 11, Nov, 2018, E-ISSN: 2222-6990 @ 2018 HRMARS

\section{INTRODUCTION}

Tanzania's tourism earnings increased by 12.1 percent to USD 2,131.6 million in 2016, from USD $1,902.0$ million recorded in 2015. The surge was mainly driven by the number of arrivals, which increased to $1,284,279$, being 12.9 percent higher than the number recorded in 2015 . Out of the total USD 2,131.6 million, USD 1,790.8 million was earned from tourists who came for leisure and holidays. Similarly, Zanzibar earnings increased by 30.4 percent to USD 383.0 million in 2016 compared with USD 293.5 million earned in 2015 owing to increase in the number of arrivals. Most of the Zanzibar earnings (USD 378.2 million) were received from visitors who came for leisure and holidays (NBS, 2017).

Hotel industry in Tanzania has experienced a tremendously growth in relation to the privatization policy and globalization from the year 1990s. The focus was to make the sector competitive and attractive so as to couple with the development of tourism sector. Prior liberalization the hotel industry in Tanzania was controlled by the government under special department in the ministry of natural resources and tourism, by then distribution of hotels in Tanzania was located in the priority region with the flag name of concerned city or township like; Kilimanjaro hotel, Mwanza hotel Arusha hotel, and Dodoma hotel.

Late 1990s and early 2000s Tanzania started to experience transformation of hotel ownership from the government bases to private sector and also the development of tourism industry. This lead to the flow of many tourist from different parts of the world to Tanzania, Also restructuring of tourism policy, advertising of national tourists potentials such as game reserves and national parks have attract many tourist to the country. Consequently hotel sector has now increasingly focusing their effort on quality of customer services as the means of differentiation, providing quality that satisfy customers has become a major source of competitive advantages for many firms and hotels as it reduces price elasticity and build loyalty as well as customer retention (Anderson and Fornell, 1994:242).

The study was conducted to assess mainly on the degree of service quality provided especially by the tourist hotels in Tanzania. The study was also executed to analyze the customer satisfaction basing on service quality in the tourism environment. The problem statement was to determine the service quality provided and how does it satisfy customer, in this study the SERVQUAL approach suggested by Parasuraman, Zeithaml, and Berry (1988), was used to assess service quality and customer satisfaction on hotel industry in Tanzania. SERVQUAL is applicable in the context of hotel industry and also identifying what Dimensions of service quality are consumers satisfied with in hotels and hence finding out the overall perceived service quality and customer satisfaction.

According to (Kweka, 2004), Good tourism environment is one of the major facilitator of tourists coming into the country. Tourists need to be assured of good place for accommodation, recreation, shopping, land transport, Safety and food. All these assurance starts from the hotels which receive the tourists. Tourism as a service industry has to ensure that the delivering of quality services is prerequisite to ensure that the customer obtain value for money. However the quality of service being offered in Tanzania hotels has been put in question as to whether they satisfy tourist arriving in the country. This is due to the fact that hotels have been faced with a number of mismanaged 
INTERNATIONAL JOURNAL OF ACADEMIC RESEARCH IN BUSINESS AND SOCIAL SCIENCES

Vol. 8, No. 11, Nov, 2018, E-ISSN: 2222-6990 @ 2018 HRMARS

problems such as inconsistency in water and electricity supply to the hotels, poor infrastructure particularly the road network leading to tourist national parks and beaches along with inefficient communication and information facilities such as internet, expensive reliable energy and provision of telephone services whose tariffs are so high (Onyango Emmanuel, 2009). It was thus the intention of this study to examine the quality of hotels services offered to tourist in Tanzania national parks and game reserves.

The goals of this paper is therefore firstly, to determine the overall service quality perceived by tourist in Tanzania hotel and identify dimensions that bring satisfaction to the tourists and secondly to evaluate the level of tourists satisfaction with the service offered by Tanzania hotels. The paper is also significant to determine the overall service quality perceived by tourists in Tanzania hotel and identify dimensions that bring satisfaction to the tourists by providing knowledge on the importance of improving service quality to the customers (tourists) to increase tourists satisfaction and enable them maintain high level of competitiveness with other countries.

\section{RELATED LITERATURE REVIEW}

\section{Tourism Trend in Tanzania Economy}

The growth of tourism sub sector in Tanzania is also encouraging going by the available data. The revenue collected in Tanzania from tourism business has increased, and the number of tourists, who visited Tanzania, has increased from 1,137,182 in 2015 to 1,284,279 in 2016 (NBS, 2017). During the trading period, big tourist hotels in Tanzania played the most crucial role in promoting the industry by providing accommodation to the visitors. The revenue collected from the tourism business also increased by far. In Spite of this increase in revenue from tourism, the number of tourist hotels in the country increased also. The increase in number of hotels logically increased the number of hotel rooms and beds available to tourists. The average numbers of days spent by tourists in Tanzania however increased correspondingly according to the demand. The only part of tourism, which enlisted a higher growth rate, was cultural tourism, archives and antiquities. PWC estimates a growth in available rooms of $2.0 \%$ compounded annually with the number of available rooms increasing from 7,700 in 2016 to 8,500 in 2021, and projects guest nights to rise from 1.6 million in 2016 to 1.8 million in 2021, a $2.4 \%$ compound annual increase. PWC projects the average daily rate of hotels (ADR) to increase from USD140 in 2016 to USD 174 in 2021, and total room revenue to expand by $6.9 \%$ compounded annually, rising to USD 371 million in 2021 from USD 224 million in 2016. Tourism is the largest industry in Tanzania, accounting for more than $17 \%$ of GDP (PWC, 2017)

\section{Conceptualization of Customer Satisfaction and Service Quality}

Service quality and customer satisfaction have received a great deal of attention from both scholars and practitioners because of its relevancy and relationships (Eshghi, Roy, and Ganguli, 2008). And the main reason for focusing on these issues is improving overall performance of organizations (Magi and Julander, 1996, p.40). Due to intense competition and the hostility of Environmental factors, service quality has become a cornerstone marketing strategy for Companies. This highlights how important improving service quality is to the organizations for their survival and growth since it could help them 
INTERNATIONAL JOURNAL OF ACADEMIC RESEARCH IN BUSINESS AND SOCIAL SCIENCES Vol. 8, No. 11, Nov, 2018, E-ISSN: 2222-6990 @ 2018 HRMARS

tackle these challenges they face in the competitive markets (Asubonteng, McCleary and Swan, 1996).

There is however, a need for the firm to understand what service quality is in order to attain their objectives. In service marketing literature, service quality is generally defined as the overall assessment of a service by the customers (Eshghi et al., 2008, p.121) or the extent to which a service meets customer's needs or expectations, Asubonteng et al., (1996). Parasuraman et al., (1985) define service quality as "The discrepancy between consumers' perceptions of services offered by a particular firm and their expectations about firms offering such services". In the context of hotel industry, If what is perceived is below expectation, tourists judges quality as low and if what is perceived meets or exceeds expectation then tourists sees quality to be high. Critical component of service quality identified are; consumer's expectation which is seen as what they feel service provider should offer and this is influenced by his/her personal needs, past experience, word-of-mouth and service provider's communications, Parasuraman et al., (1985, p.49).

\section{Empirical Review}

According to different studies service quality mainly focus in meeting tourists need in the tourism environment It is however difficult according to previous studies to measure service quality because of its intangible nature which is hard to quantify. (Eshghi et al., 2008, p.121); (Douglas \& Connor, 2003, p.171), also because it deals with expectations and perceptions of consumers which is difficult as well to determine due to the complexity of human behavior. In the hotel industry the services provided are intangible thus become so difficult to measure its quality, This means that service providers must try to determine the level of intangibility of services and try to include tangible elements that could aid understanding of expectation from the consumer's perspective (Beamish \& Ashford, 2007, p.240).

In this study therefore, service quality is taken as the difference between what tourists expect from each of the service quality attributes and what the tourist eventually perceives to have received while visiting Tanzania hotels. In this regard, we conceptualize satisfaction as, if the tourists' expectations exceed their initial perceptions then the hotels are considered as providing low-quality services and vice versa.

Tourists, like other customers, usually have initial expectations of the type and quality of services to be offered in a particular destination. The extent to which tourist expectations are met will eventually determine the level of tourist satisfaction. The most critical factors to excelling at serving the most profitable guests a reality measuring service quality and being able to defend pricing strategies is the first major trend that the hospitality industry today is continually working through to find a profitable solution for. The use of the SERVQUAL as a measure of service quality and satisfaction for quantifies factors that most and least delight guests staying at a hotel. This is invaluable analysis and can assist hospitality managers in defining processes, systems and work flows that can further sustain customer satisfaction over the long-term. 
INTERNATIONAL JOURNAL OF ACADEMIC RESEARCH IN BUSINESS AND SOCIAL SCIENCES Vol. 8, No. 11, Nov, 2018, E-ISSN: 2222-6990 @ 2018 HRMARS

Research Gap between Customer Satisfaction and Service Quality in Hotel Industry

Various studies that focused on a link between satisfaction and quality argued for different views in terms of relationship. Some think that quality leads to satisfaction, McDougall \& Levesque, (1996, 2000); Negi, (2009) and others support that satisfaction leads to quality (Cronin \& Taylor, 1992). Though Customer satisfaction is based on the level of service quality delivered by the service providers (Saravanan \& Rao, 2007, p.436) in the hotel industry, the tourists' satisfaction will depend on the degree of service quality received. Overall service satisfaction and perception of service quality are all interrelated and according to Bitner and Hubbert (1994:78) and in many instance, highly correlated.

\section{METHODOLOGY}

\section{Design of the Study}

Exploration study was carried out because little or none study have been conducted to assess the level of tourists satisfaction in Tanzania hotels. 50 Questions were made basing on SERVQUAL model of six dimensions such as Tangibility, Reliability, Responsiveness, Assurance, Empathy and Price. The unit of analysis was explored in Dar-es salaam region to 150 respondents from various hotels such as Serena hotel, Moven pick hotel, Hyatt regency hotel, giraffe hotel, white sand hotel, beach Comba hotel, and southern sand hotel. Collection of data using a self-completion questionnaire was developed from the SERVQUAL instrument and distributed to the tourist in Dar-es -salaam region to determine their perception of service quality in hotel industry. The Gap model/SERVQUAL approach was suggested by Parasuraman, Zeithaml, and Berry (1988), in a way of trying to measure quality of services offered by various institutions, researchers developed a methodology known as SERVQUAL.

This type of methodology came as a result of varied range of factors that customers experienced prior to the services being offered and the factors that customers felt after receiving the service. Thus, there was a need to develop a perceived service quality questionnaire that would examine possible dimensions pertaining to the services being offered. These dimensions include Tangibility, Reliability, Responsiveness, Assurance, Empathy and Price. In conducting SERVQUAL analysis, each dimension of service quality was measured in terms of customers' expectations and perceptions on a scale of 1 to 5 range of satisfaction using SPSS 17.

Then, each of the six dimensions was weighted according to customer importance, and the score for each dimension was multiplied by the weighting. Following this, the Gap Score for each dimension was calculated by subtracting the Expectation score from the Perception score. A negative Gap score indicated that the actual service (the Perception score) was less than what was expected (the Expectation score) and vice versa. The Gap score is a reliable indication of each of the six dimensions of service quality. Using SERVQUAL, service providers can obtain an indication of the level of quality of their service provision, and highlight areas requiring improvement.

\section{Significance of the Model}

The SERVQUAL model is used as main concept to assess service quality and customer Satisfaction. This means that customer satisfaction could be measured using the various service quality 
dimensions. This is because it is important to be aware of how customers perceive service quality in hotels and the factors that affect these perceptions. SERVQUAL model is a good scale to use when measuring service quality in various Specific industries because it takes into account customer's expectation of a service as well as perceptions of the service which is best way to measure service quality in service sector. (Shahin, 2005, p.3) Buttle, (1996, p.8) mention several researchers that have used the SERVQUAL model in various industries (retailing, restaurants, banking, telecommunication industry, airline catering, local government, hotels, hospitals, and education). It is then imperative to use SERVQUAL model while analyzing customer expectation of the service as well as perception of the services through various dimensions like tangibility, responsiveness, assurance, Reliability, empathy, price in the hotel industry. Thus, the researcher used SERVQUAL model to analyze service quality and customer satisfaction in tourist hotel industry in Tanzania.

\section{EMPIRICAL RESULT AND DISCUSSION}

\section{Variable Description}

Variables used in this study were six dimensions of service quality namely Tangibility (TAN) with four observed (manifest) variables; Reliability (REL) with five observed variables; Responsiveness (RES) with four observed variables; Assurance (ASS) with four observed variables, Empathy (EMP) with five observed variables and Price (PR) with three observed variables. The study collected primary data from 150 respondents and the responses were based on a five point Likert scale i.e. $(1=$ very dissatisfied; 2 = dissatisfied; 3 = just as satisfied; 4 = satisfied and $\mathbf{5}$ = very satisfied)

\section{Descriptive Statistics}

Descriptive statistics provide short summary of basic information regarding each manifested variable. This information is based on the mean score and standard deviation which was also obtained using a five-point Likert scale. This scale indicates tourists' level of satisfaction on the services provided in Tanzania hotels. This study also included Cronbach's alpha coefficient under descriptive statistics to measure reliability of the data (expectation and perception variables) before moving to further analysis of the study.

Table 4.1 Summary Statistics and Reliability Measure (Expectation Variables)

\begin{tabular}{|c|c|c|c|c|c|}
\hline Dimension & items & observations & mean & $\begin{array}{l}\text { Std. } \\
\text { Deviation }\end{array}$ & Alpha \\
\hline TAN & 4 & 150 & 4.3 & 0.6 & \\
\hline REL & 5 & 150 & 4.4 & 0.6 & \\
\hline RES & 4 & 150 & 4.3 & 0.6 & \\
\hline ASS & 4 & 150 & 4.3 & 0.6 & \\
\hline EMP & 5 & 150 & 4.1 & 0.7 & \\
\hline PR & 3 & 150 & 3.8 & 0.9 & \\
\hline & & & Cronbach's & Alpha & .624 \\
\hline
\end{tabular}

Source: Researcher's Field Data Analysis, 2018. 
INTERNATIONAL JOURNAL OF ACADEMIC RESEARCH IN BUSINESS AND SOCIAL SCIENCES Vol. 8, No. 11, Nov, 2018, E-ISSN: 2222-6990 @ 2018 HRMARS

Table 4.1 above indicates summary statistics for overall manifested expectation variables regarding all dimensions. It can be seen that most of the mean scores for responses were "satisfied" with the quality of services expected to be offered in Tanzanian hotels. Also, Cronbach's alpha coefficient was used to measure the internal consistence of the data (reliability), under which values greater than 0.5 were regarded to be acceptable. The overall Cronbach's alpha coefficient for all dimensions (expected) was 0.624 indicating a good reliability. Thus, all variables were worth to be retained for further analysis.

Table 4.2 Summary Statistics and Reliability Measure (Perception Variables)

\begin{tabular}{|l|l|l|l|l|l|}
\hline Dimension & items & observations & mean & $\begin{array}{l}\text { Std. } \\
\text { Deviation }\end{array}$ & Alpha \\
\hline TAN & 4 & 150 & 4.3 & 0.7 & \\
\hline REL & 5 & 150 & 4.4 & 0.6 & \\
\hline RES & 4 & 150 & 4.2 & 0.7 & \\
\hline ASS & 4 & 150 & 4.1 & 0.7 & \\
\hline EMP & 5 & 150 & 3.9 & 0.8 & \\
\hline PR & 3 & 150 & 3.7 & 0.9 & .623 \\
\hline & & & Cronbach's & Alpha & \\
\hline
\end{tabular}

Source: Researcher's Field Data Analysis, 2018.

Table 4.2 above indicates summary statistics for overall manifested variables (perception) regarding all dimensions. It can be seen from the table that most of the mean scores for responses were perceived as "satisfied" to the quality of services offered in Tanzania hotels, although slightly lower than expectation results. With regards to reliability measure of the data, Cronbach's alpha coefficient for all dimensions (perception) was 0.623 indicating a good reliability.

Table 4.3 SERVQUAL Scores (Unweighted Average Calculated)

\begin{tabular}{|l|l|l|l|l|l|}
\hline Dimension & Statement & $\begin{array}{l}\text { Expectation } \\
\text { Score }\end{array}$ & $\begin{array}{l}\text { Perception } \\
\text { Score }\end{array}$ & $\begin{array}{l}\text { Gap } \\
\text { Score }\end{array}$ & $\begin{array}{l}\text { Average for } \\
\text { Dimension }\end{array}$ \\
\hline Tangibles & 1 & 4.35 & 4.23 & -0.11 & -0.03 \\
\hline & 2 & 4.37 & 4.35 & -0.02 & \\
\hline & & & & & \\
& 3 & 4.43 & 4.40 & -0.03 & \\
\hline & 4 & 4.22 & 4.28 & 0.06 & \\
\hline Reliability & 1 & 4.46 & 4.33 & -0.13 & -0.06 \\
\hline & 2 & 4.21 & 4.41 & 0.20 & \\
\hline & 3 & 4.51 & 4.35 & -0.16 & \\
\hline & 4 & 4.33 & 4.35 & 0.01 & \\
\hline & 5 & 4.56 & 4.34 & -0.22 & \\
\hline Responsiveness & 1 & 4.13 & 4.22 & 0.09 & -0.05 \\
\hline & 2 & 4.45 & 4.33 & -0.12 & \\
\hline
\end{tabular}


INTERNATIONAL JOURNAL OF ACADEMIC RESEARCH IN BUSINESS AND SOCIAL SCIENCES Vol. 8, No. 11, Nov, 2018, E-ISSN: 2222-6990 @ 2018 HRMARS

\begin{tabular}{|l|l|l|l|l|l|}
\hline & 3 & 4.27 & 4.15 & -0.11 & \\
\hline & 4 & 4.30 & 4.25 & -0.05 & \\
\hline Assurance & 1 & 4.25 & 4.13 & -0.13 & -0.18 \\
\hline & 2 & 4.49 & 4.28 & -0.21 & \\
\hline & 3 & 4.26 & 4.15 & -0.11 & \\
\hline & 4 & 4.30 & 4.02 & -0.28 & \\
\hline Empathy & 1 & 4.23 & 4.07 & -0.16 & -0.26 \\
\hline & 2 & 4.19 & 3.98 & -0.21 & \\
\hline & 3 & 3.97 & 3.48 & -0.49 & \\
\hline & 4 & 4.17 & 3.99 & -0.19 & \\
\hline Price & 5 & 4.10 & 3.85 & -0.25 & \\
\hline & 1 & 3.85 & 3.69 & -0.16 & -0.10 \\
\hline & 2 & 3.72 & 3.61 & -0.11 & \\
\hline & 3 & 3.89 & 3.87 & -0.02 & \\
\hline Unweighted Average SERVQUAL Score: & & & \\
\hline
\end{tabular}

Source: Researcher's Field Data Analysis, 2018.

Table 4.3 above indicates SERVQUAL score calculations for each of the manifested variables under all dimensions. Results indicated negative gap scores in most of the dimensions used in the study. This means that the actual hotel services offered to tourists in Tanzania are less than what was expected. However, the results also indicated positive level of satisfaction on the appealing nature of the materials associated with hotel services (TAN04), hotels' interest in solving customers' problems (REL02), punctuality of hotel services (REL04) and readiness of hotels in offering services to their customers (RES01).

Table 4.4 Importance Weights

\begin{tabular}{|c|c|}
\hline Features & Points \\
\hline $\begin{array}{l}\text { 1. The appearance of the hotel physical facilities, equipment, personnel and } \\
\text { communication materials. }\end{array}$ & 4 \\
\hline $\begin{array}{l}\text { 2. The hotel's ability to perform the promised service dependably and } \\
\text { accurately }\end{array}$ & 9 \\
\hline 3. The hotel's willingness to help customers and provide prompt service. & 7 \\
\hline $\begin{array}{l}\text { 4. The knowledge and courtesy of the hotel's employees and their ability to } \\
\text { convey trust and confidence. }\end{array}$ & 27 \\
\hline 5. The caring individual attention hotel provides to their customers. & 39 \\
\hline $\begin{array}{l}\text { 6. Affordability and reasonability of the price range set in hotel's services, } \\
\text { facilities and entertainments. }\end{array}$ & 15 \\
\hline Total: & 100 \\
\hline
\end{tabular}

Source: Researcher's Field Data Analysis, 2018. 
INTERNATIONAL JOURNAL OF ACADEMIC RESEARCH IN BUSINESS AND SOCIAL SCIENCES Vol. 8, No. 11, Nov, 2018, E-ISSN: 2222-6990 @ 2018 HRMARS

Table 4.4 above, indicates dimensions' importance weights as ranked from the respondents' markings as seen in table 4.3 above. The importance score indicates specific dimensions that are to be considered for change or improvements. From the table, the highest ranking was Empathy dimension with 39 scores of importance. This score implies that, caring and attention of hotel employees to tourists are highly considered when determining tourists' satisfaction. Another important weight was Assurance dimension with 27 scores of importance. This also implies that hotel employees should be well knowledgeable to assure tourists with the quality of services.

Table 4.5 SERVQUAL Scores (Weighted Average Calculated)

\begin{tabular}{|l|l|l|l|}
\hline $\begin{array}{l}\text { SERVQUAL } \\
\text { Dimension }\end{array}$ & $\begin{array}{l}\text { Score from } \\
\text { Table 4.3 }\end{array}$ & $\begin{array}{l}\text { Weighting from } \\
\text { Table 4.4 }\end{array}$ & $\begin{array}{l}\text { Weighted } \\
\text { Score }\end{array}$ \\
\hline Tangibility & -0.03 & 4 & -0.1 \\
\hline Reliability & -0.06 & 9 & -0.5 \\
\hline Responsiveness & -0.05 & 7 & -0.3 \\
\hline Assurance & -0.18 & 27 & -4.9 \\
\hline Empathy & -0.26 & 39 & -10.0 \\
\hline Price & -0.10 & 15 & -1.5 \\
\hline Average Weighted score: & & -17.4 \\
\hline
\end{tabular}

Source: Researcher's Field Data Analysis, 2018.

Table 4.5 above indicates weighted SERVQUAL scores for all dimensions. As seen above, tourists were less satisfied with hotels' empathy followed by assurance and price dimensions. SERVQUAL Average with -17.4 weighted score indicates the level of dissatisfaction on all dimensions of services offered to tourists in Tanzanian hotels.

\section{Demographic Information}

This section provides the summary of demographic information for all respondents. It describes the gender of the respondent; the age group of the respondent, regions in which the respondent belongs to, and the number of times in which the respondent has visited in hotels. Consider table 4.6 below: 
INTERNATIONAL JOURNAL OF ACADEMIC RESEARCH IN BUSINESS AND SOCIAL SCIENCES Vol. 8, No. 11, Nov, 2018, E-ISSN: 2222-6990 @ 2018 HRMARS

Table 4.6: Respondents' Demographic Information

\begin{tabular}{|c|c|c|c|c|c|}
\hline Demographics & Label & Frequency & $\begin{array}{l}\text { Percentage } \\
(\%)\end{array}$ & Mean & $\begin{array}{l}\text { Standard } \\
\text { Deviation }\end{array}$ \\
\hline \multirow[t]{3}{*}{ Gender } & Female & 66 & 44.0 & & \\
\hline & Male & 84 & 56.4 & & \\
\hline & Total & 150 & 100 & 1.56 & 0.498 \\
\hline \multirow[t]{6}{*}{ Age Group } & $18-29$ yrs & 2 & 1.3 & & \\
\hline & $30-41$ yrs & 50 & 33.3 & & \\
\hline & $42-53$ yrs & 80 & 53.3 & & \\
\hline & $54-65$ yrs & 17 & 11.3 & & \\
\hline & $\begin{array}{ll}\text { Above } 65 \\
\text { yrs }\end{array}$ & 1 & 0.7 & & \\
\hline & Total & 150 & 100 & 2.77 & 0.689 \\
\hline \multirow[t]{7}{*}{ Region } & Africa & 11 & 7.3 & & \\
\hline & Asia & 17 & 11.3 & & \\
\hline & Australia & 29 & 19.3 & & \\
\hline & Europe & 63 & 42.0 & & \\
\hline & $\begin{array}{l}\text { North } \\
\text { America }\end{array}$ & 24 & 16.0 & & \\
\hline & $\begin{array}{l}\text { South } \\
\text { America }\end{array}$ & 6 & 4.0 & & \\
\hline & Total & 150 & 100 & 3.60 & 1.215 \\
\hline \multirow{5}{*}{$\begin{array}{ll}\text { Frequency } & \text { of } \\
\text { visits } & \text { to } \\
\text { Tanzanian } & \\
\text { hotels } & \\
\end{array}$} & Once & 75 & 50.0 & & \\
\hline & Twice & 51 & 34.0 & & \\
\hline & Thrice & 18 & 12.0 & & \\
\hline & $\begin{array}{l}\text { More than } \\
\text { thrice }\end{array}$ & 6 & 4.0 & & \\
\hline & Total & 150 & 100 & 1.70 & 0.833 \\
\hline
\end{tabular}

Source: Researcher's Field Data Analysis, 2018.

Table 4.6 above shows that male respondents were 84 (56\%), while females representatives were 66 (44\%) slightly lower than males. Age groups between $30-41$ and $42-53$ appeared by $33.3 \%$ and $53.3 \%$ respectively, indicating a working class who always has time for their vacations. This also indicates that data was mostly collected from the adult respondents who had knowledge and experience in quality of tourism and hotel services, and thus assured reliability of the data. Also 
INTERNATIONAL JOURNAL OF ACADEMIC RESEARCH IN BUSINESS AND SOCIAL SCIENCES

Vol. 8, No. 11, Nov, 2018, E-ISSN: 2222-6990 (C) 2018 HRMARS

Europe appeared by $63 \%$ in regional category, which implied that above average, the main market for tourist hotels depend largely on European tourists.

\section{Conclusion and Recommendation Conclusion}

This study intended to carry out SERVQUAL model in order to determine the overall service quality perceived by tourists in Tanzania hotel and identify those dimensions that bring satisfaction to tourists. Thus, the study used SERVQUAL six dimensions namely Tangibility, Reliability, Responsiveness, Assurance, Empathy and Price as the main variables for the study. Data was collected from 150 respondents and reliability coefficient (Cronbach's alpha) was used to measure reliability of the data. The overall Cronbach alpha values for expectation and perceptions variables were -624 and -623 respectively. This assured internal consistence of the data and thus guaranteed the researcher for further analysis of the study.

Under SERVQUAL model, from the gap score analysis carried out, it was found that, the actual hotel services offered to tourists in Tanzania are less than what was expected. However, the results also indicated positive level of satisfaction on the appealing nature of the materials associated with hotel services (TAN04), hotels' interest in solving customers' problems (REL02), punctuality of hotel services (REL04) and readiness of hotels in offering services to their customers (RES01). To answer our research questions which are; how tourists perceive service quality and are they satisfied with services offered by Tanzania hotel, the gap scores analysis carried out provided answers to these questions.

The study concluded that overall perceived service quality is low as expectation exceeded perception which means tourist in hotel are offered less than what they actually expect. As a result of this gap, it is clear that tourists are dissatisfied. Generally the study concluded that the tourist are not satisfied in almost all dimension, thus Tanzania hotels need to improve in their performance for the purpose of bringing tourist satisfaction.

\section{Recommendation}

The study indicate that there is high level of tourist dissatisfaction in the Empathy dimension (EMP) as its average score range to $(-0.26)$. This show that the hotels doesn't give the customers individual attention (EMP01), also the hotel doesn't provide the customers best interest at heart (EMP04) and lack of employee understand on the specific needs to their customers (EMP05). Thus empathy dimension needs to be improved by the Tanzania hotel for the purpose of ensuring customer satisfaction.

The second high dimension which shows tourist dissatisfaction is assurance (ASS). As its average score range to $(-0.18)$. This prove that the hotels employees are not consistently courteous with the customers (ASS03), also customers in hotels do not feel safe in transactions (ASSO2) and lack of employees sufficient knowledge to answer the customers questions in hotels.(ASSO4). Thus 
INTERNATIONAL JOURNAL OF ACADEMIC RESEARCH IN BUSINESS AND SOCIAL SCIENCES

Vol. 8, No. 11, Nov, 2018, E-ISSN: 2222-6990 @ 2018 HRMARS

assurance dimension need to be improved by Tanzania hotels for the purpose of ensuring customer satisfaction.

Price (PR) dimension indicate also a high average score of $(-0.10)$. this manifest that tourist are dissatisfied with the price charged by the hotels (PR01), also are not satisfied with the price of accommodation and catering facilities (PR02). Thus hotels need to check on the prices charged to the tourist for the purpose of encouraging tourist satisfaction.

In other dimensions such as tangibility (TAN,) reliability (REL) and responsiveness (RES), the average score was $-0.03,-0.06$ and -0.05 respectively. In these dimensions the study shows that tourists were dissatisfied with the exception of (TAN04) on the appealing nature of materials associated with the hotels also (REL02) show that tourists are satisfied with the hotels interest in solving problems moreover (REL01) and (REL04) indicate tourists satisfaction on the punctuality of hotels services and readiness of hotels in offering services to their customers.

The study also indicates that, tourists are satisfied with the appealing nature of materials associated with the hotels this is evident in hotels such as Hyatt regency, southern sand and Moven pick also tourists are satisfied with the hotels interest in solving problems, punctuality of hotels services and readiness of hotels in offering services to their customers. Evaluating the perceptions and expectations of tourists, it can be seen that almost every dimension of service quality brings tourist dissatisfaction as tourists were not satisfied with hotels services. Basing on the analysis of the study, it is evidenced however, that Tanzania hotels have to improve performance on all the dimensions of service quality in order to increase tourist satisfaction and enable them maintain high level of competitiveness with other countries.

Researchers however, advise the government of Tanzania to assure sound tourism environment to those investing and running tourist hotels by reducing tax so as price on these hotels can be affordable, formation of good strategies on promoting tourism to bring as many tourists possible, organizing many tourism training schools and institutions to train and educate staffs rather than employing unqualified ones and also the government should improve infrastructures like transportation, telecommunications and internet. Tanzania can utilize the political stability and well known and down to earth cultural background as a tool to make tourism the best source of income and invite as many people to invest on it. 
INTERNATIONAL JOURNAL OF ACADEMIC RESEARCH IN BUSINESS AND SOCIAL SCIENCES

Vol. 8, No. 11, Nov, 2018, E-ISSN: 2222-6990 @ 2018 HRMARS

\section{References}

1. Asubonteng, P., McCleary, K.J. and Swan, J.E. (1996). SERVQUAL revisited: a critical Review of service $\quad$ quality, The Journal of Services Marketing, Vol.10 p.62-81.

2. Beamish, K. \& Ashford, R. (2007/2008). Marketing Planning. 1st Edition. Oxford OX2 8DP, UK. Butterworth-Heinemann.

3. Bitner, M. J. \& Hubbert, A. R. (1994). Encounter satisfaction versus overall satisfaction versus quality: the customer's voice. service quality: new directions in theory and practice, Thousand Oaks, CA: Sage(In Rust, R.T., \& Oliver, R.L. (Eds.), 72-94

4. Buttle, F. (1996). SERVQUAL; review, critique, research agenda, European Journal of Marketing, Vol. 30, Number 1, p.8-32.

5. Cronin, J.J. and Taylor, S.A. (1992), "Measuring service quality: a reexamination and extension", Journal of Marketing, Vol. 6, July, pp. 55-68.

6. Douglas, L. \& Connor, R. (2003). Attitudes to service quality- the expectation gap, Nutrition \& Food Science, Vol. 33 Number 4, p.165-172.

7. Eshghi, A., Roy, S. K., and Ganguli, S. (2008). Service quality and customer satisfaction, An empirical Investigation in Indian mobile Telecommunications services, Marketing Management Journal, Vol 18, p. 119-144.

8. Global professional services firm, https://www.tanzaniainvest.com/tourism/pwc-estimate2017-2021 (accessed 6 September 2018)

9. Kweka, J. (2004), Tanzania economy and tourism development, oxford. UK.

10. Magi, A. and Julander, C. R. (1996). Perceived service quality and customer satisfaction in a store Performance framework, an empirical study of Swedish grocery Retailers, Journal of Retailing and consumer services, Vol. 3, p.33-41

11. McDougall \& Levesque $(1996,2000)$ "Determinants of customer satisfaction in retail banking", International Journal of Bank Marketing, Vol. 14 Issue: 7, pp.1220, https://doi.org/10.1108/02652329610151340

12. Negi, R. (2009). Determining customer satisfaction through perceived service quality: A study of Ethiopian mobile users, International Journal of Mobile Marketing; Vol.4, Number 1; p.3138

13. Onyango, E. (2009), journal on the Development of tourism industry sector in Tanzania.

14. Parasuraman, A. Zeithaml, V. A. and Berry, L. L. (1988). SERVQUAL: A multiple-item scale for measuring Consumer perceptions of service quality, Journal of Retailing, Vol. 64, p.12-40.

15. Parasuraman, A., Zeithaml, V. A., and Berry, L. L. (1985). A conceptual model of service Quality and its implications for future research, Journal of Marketing, Vol. 49,

16. Saravanan, R. \& Rao, K. S. P. (2007). Measurement of service quality from the customer's perspective - An empirical study, Total Quality Management, Vol. 18. No. 4, p.435-449

17. Shahin, A. (2005). SERVQUAL and Model of Service Quality Gaps: A framework for determining and prioritizing critical factors in delivering quality services, Department of Management, University of Isfahan, Iran, p.1-10.

18. Tanzania tourism sector survey http://www.nbs.go.tzf (accessed 6 September 2018) 